\title{
새마을 운동 ODA 현황과 전망
}

- 이론적 논의와 사업 확대방안을 중심으로 ${ }^{*}-$

김 성 규 (KOICA ODA연구팀 상임연구원)

\section{목 차}

1. 서론 : 문제의식

2. 이론적 논의 : 새마을운동을 보는 시각

3. 새마을 운동 ODA 사업모델 형성과 평가 틀

4. 개도국 새마을 운동 ODA 사업사례 분석

5. 결론 : 새마을 운동 ODA 확대방안

\section{1. 서론 : 문제의식}

최근 한국과 국제사회에서 새마을 운동 ODA 담론이 뜨거운 쟁점으로 떠오르고 있으며, 이 에 대해 그 배경과 실제 사업성과를 중심으로 다양한 해석과 논의가 진행되고 있다. 그런데 과 거 농촌개발 사업 중심의 새마을 운동 ODA가 실제 개도국 빈곤퇴치에 기여한 점, 수원국 국 민들의 원조 수용 태도 관점에서 이들을 수동적 지원 대상에서 동기화된 주체로 변화시킨 점, 그리고 개도국 빈곤 지역의 공동체 복원과 거버넌스 형성에 기여한 점 등은 주목할 만한 성과 로 평가되고 있다.

* 본 논문은 김성규(2013), 개도국 지역공동체개발 논의 동향과 전망 : 새마을운동 ODA정책과 사업전략 형성을 위한 시사 점, 개발협력 정책과 이슈 11호, KOICA 와 김성규(2013), 개도국 지역공동체개발 사업 사례 연구 : 새마을운동 ODA 확 대 가능성을 중심으로, 개발과 이슈 13호, KOICA 를 바탕으로 재구성 함. 
또한 개발협력 맥락에서 새마을 운동 ODA와 농촌지역공동체 개발 사업의 결합은 사업의 포 괄성(inclusiveness), 지속가능성(sustainability) 측면에서, 그리고 원조사업 확대를 위한 기 반형성을 가능하게 한다는 점에서 중요한 의미와 비전을 갖는다. 즉, 해당 사업은 지역 네트워 킹 지원이라는 무형의 사회적 자본 축적 과정에서부터 마을 인프라의 구축, 커뮤니티 비즈니 스의 개발 지원 등까지를 아우르는 보다 포괄적이고 다면적인 사업형성을 가능하게 한다. 아 울러 사업에는 수원국의 사회, 경제, 환경, 삶의 질, 인권, 지역 민주주의 발전 등을 고려한 범 분야적(cross-cutting) 이슈를 포함할 수 있다. 또한 사업의 높은 지속가능성에 주목할 필요 가 있다. 즉, 단기적 빈곤퇴치 뿐만 아니라 이를 넘어선 포괄적이고도 지속가능한 성장 (inclusive and sustainable growth)을 지향하는데, 기본 철학은 '스스로 욕구를 해결하려는 노력을 지원'하고자 한다. 이는 공동체 성원들이 지역 내 구조화된 사회적 불평등(structured social inequity)의 요인을 스스로 자각 하고 이를 극복하는 대안을 찾게 하는 것과 맥을 같이 한다. 따라서 해당 사업은 원조의 핵심 목표인 수원국 주민의 태도와 인식 변화, 스스로의 동 기부여(self-motivation)에 있어 다른 어떤 사업보다도 효과성을 가질 수 있다고 평가될 수 있다.

이러한 배경 하에 본 글은 한국의 새마을 운동과 개발협력 차원에서의 관련 ODA 이론적 동 향 정리, 실제 수행된 한국의 지자체와 $\mathrm{KOICA}$ 사업 사례 분석과 이를 통한 향후 새마을 운동 $\mathrm{ODA}$ 사업 전략 제시와 확대 방안 마련에 일조하고자 한다. 사업 사례 분석에서는 한국의 지 자체와 새마을운동 중앙회의 집중 지원 지역이었던 몽골과 KOICA 농촌 개발 사업의 모범 사 례로 꼽히는 미얀마 흘레구 지역 농촌개발 지원 사업을 비교했다.

\section{2. 이론적 논의 : 새마을운동을 보는 시각}

개발협력의 시각에서 한국의 새마을 운동은 (1) 농촌개발(rural development) (2) 도시화 (urbanization), 산업화 (3) 거버넌스(governance) 형성 등 다면적 측면에서 분석이 시도되어 야 한다. 실제로 70 년대 새마을 운동을 통해 추진되었던 농촌개발 사업은 당시의 산업화, 도 시화 현상, 지역사회 거버넌스 형성과 밀접한 연관성 하에서 수행되었다2). 또한 당시 정부의

2) 70 년대 국가 성장 동력으로 추진되었던 산업화와 이로 인한 도시화 등은 새마을 운동의 주요 추진 배경이 되었다. 당시 농지개혁은 한국 사회가 전통적 농업국가에서 현대적 공업국가로 전환하는 계기로 작용했으며, 신분질서에서 벗어난 농 민 층 자녀들은 교육의 기회를 갖거나 산업화의 기반이 된 도시지역 노동자 군으로 형성되었다. 
농촌 가구 동원능력은 매우 강력했던 것으로 보인다3). 따라서 당시 한국 정부의 높은 동원력 이 가능했던 유·무형의 자원에 대한 분석이 필요하며, 이는 관련분야의 주요 연구과제로 설정 되고 있다.

1970년대 정부가 주도했던 새마을 운동은 외국의 학계에서는 흔히 한국식 참여형 개발 (participatory development)의 상징으로 인식된다. Douglass(2012) 등은 한국의 새마을 운 동은 도시화와 대비되는 농촌지역의 '잘살아보기' 혹은 '농촌 마을 업그레이드' 성격 외에, 대 기업 탈 중심화 지향 정책 등 당시 진행된 산업 합리화의 측면, 식량 자급자족을 위한 녹색혁 명(green revolution) 담론, 국토 균형발전을 위한 국가발전전략 등과 연결되어 이해되어야 한다고 주장한다. 즉, 산업화, 도시화로 상징되는 한국의 경제발전과 새마을운동의 성과는 상 호보완적인 시너지 효과를 가져왔으며, 실제 당시 급속하게 진행된 산업화·도시화에서 농촌은 상업용 곡물생산과 노동력 공급의 기지로 그 역할이 부여되었다4)는 주장인 것이다. 여기에 당 시 동아시아를 중심으로 대두되고 있었던 농촌개발, 식량 자급자족을 위한 녹색혁명 분위기 고조라는 외적 요인도 한국의 상황에 맞게 적용, 강조 되었다.

결국 새마을 운동의 본질적 작동과 실현 매커니즘을 규명하기 위해서는 한국 사회의 내적 사회적, 경제적 관계들을 주요하게 들여다봐야 한다는 점을 관련 논의는 강조하고 있다. 즉 당 시 새마을 운동의 작동과 발전 매커니즘은 사회적 자본과, 거버넌스의 형성정도, 그 외 도시화 의 정도, 국가 발전 전략과 행정 제도적 특성 이라는 변수들과 맞물려 있었다. 따라서 어떤 요 인을 주요 변수로 설정하느냐에 따라 연구의 관점은 달라질 수 있다. 즉 한국 사회의 전통적인 공동체 문화, 사회적 관계, 생활양식 등을 주요 작동 요인으로 보는 입장과 국가발전전략, 정 치적 목적(political agenda) 등을 작동 매커니즘의 주요 요인으로 보는 입장이 있을 수 있 다5).

한편 새마을 운동의 이해를 위해 '동아시아 근대화론'에서 보는 '농촌 역할론'을 주목해 볼 수 있다. 해당 이론에서 농촌(농업)은 매우 중요한 변수로 설정 되는데, 70 년대 동아시아 농업

3) 개도국 커뮤니티의 상황과 그간 수행된 지역 공동체 개발 관련 사업 경험을 분석해 보면, 개도국 중앙, 혹은 지방정부의 공동체 가구 동원능력은 대개 현저히 낮음을 볼 수 있다.

4) 그런데 당시 농업(농촌)에게 부여된 역할은 학자에 따라 견해가 다를 수 있다. 즉, 국가 경제 발전에 농촌지역의 ‘역할'이 중요함을 강조하는 견해와 산업화, 도시화의 '혜택'으로 농촌지역 근대화를 이룰 수 있다는 견해로 크게 구분될 수 있다.

5) 60 년대 말 한국의 개발주의(developmentalism)는 경제성장과 산업화를 통한 개발의 단계를 이론화한 이른바 '국가발 전론' 혹은 '발전단계론'과 연관된다. 당시 유엔과 세계은행 등은 '강력한 발전 지향적 국가(strong-arm development state)'의 실험에 큰 기대를 보였으며, 한국의 정책 연구기관, 정부 내 개발계획부처를 신설을 통한 강력한 기술 관료주 의적 역량 동원은 해당 사례로 자주 언급 되었다(김성규 2013). 
국가에서 수행된 국가 발전 전략은 이러한 '농촌-도시 통합개발이론' '연계이론'에 바탕을 두 고 있다. 이론에 따르면 농촌은 다음의 몇 가지 측면에서 중요한 역할이 기대된다. 첫째, 도시 에 저임금 노동자를 공급하는 노동력의 풀(pool)로서 기능한다. 둘째, 흔히 저임금 노동자는 도시 외곽에 거주하면서 도시빈민층을 형성하게 되는데, 농촌은 이들의 구매력에 맞는 저가의 농산물을 공급해야 한다. 셋째, 농산물 가격의 저가 유지를 통해 아울러 안정적인 투자 환경을 조성하는 역할을 해야 한다. 결국 이 이론은 농업사회에서 근대 산업화로 이행하는 과도기에 서의 국가 전략은 농업(농촌) 역할이 강조되어야 한다는 점이고, 이러한 맥락에서 농업(농촌) 발전의 결과가 결국 성공적 산업화, 합리적 도시화의 성공으로 이어진다는 논리이다. 결국 농 촌지역의 역할은 산업화, 도시화를 가능하게 하고 이에 따른 경제적 결과(성과)는 농촌지역에 다시 배분된다는 논리이다.

새마을 운동 ODA에 대한 평가는 크게 긍정론과 한계론으로 정리될 수 있다. 긍정론은 한국 의 개발경험이라는 무형의 자산이 개도국의 빈곤퇴치와 지역 공동체 개발 등에 긍정적 영향을 줄 수 있다는 주장과 연결되며, 실제로 과거 개발협력 과정에서 한국의 새마을 운동 정신은 개 도국 지역공동체 발전에 있어 중요한 인적, 물적, 정신적 요소로 취급되었다. 한편 한계론은 새마을 운동이 주창되었던 70년대 한국의 사회경제적 배경, 문화적 맥락이 가지는 특수성이 존재하기 때문에, 한국의 개발경험을 개도국에 단순히 이전(transfer)하는 데는 무리가 따른 다는 논리이다6). 다시 말해 한국 개발 경험의 '적용'노력이 개도국에 성공적인 '적응'으로 이어 지기엔 많은 내·외적 고려 변수들이 존재할 수 있다. 개도국 소득수준 관련 지표 등은 사업 대 상 선정에 절대적 변수가 될 수 없으며, 오히려 국가의 소득수준과는 별개로 전 지구적인 생태 적 환경이 이미 한국의 6,70 년대의 그것과는 많이 변화하였다는데 주목해야 한다. 예를 들어 통신기술과 교통수단의 발달로 인한 새로운 IT 기술·커뮤니케이션 환경의 출현, 혁신적 지식 공유의 환경 변화 등은 개발협력 사업에서 새마을 운동 ODA가 직면한 새로운 도전이다.

6) 새마을 운동은, 확산성, 지역 지도자 발굴·양성 등 성공적인 인력개발, 공동체 의식의 고양 등을 바탕으로 한 긍정론과, 서구 근대화론의 무비판적 수용, 권위주의 체제 유지를 위한 정치적 목적에 기반을 두고 있었다는, 즉 사회경제적 상황의 특수성과 정치적 의지가 결합됨으로서만 성과를 낼 수 있었다는 한계론의 시각으로 분석할 수 있다. 긍정론은 새마을 운 동의 전국적 확산성은 당시 중앙 정부의 강력한 '촉매적 역할'을 감안한다 하더라도 세계사적으로 유래가 없을 정도로 빠르고 광범위 했으며, 이는 객관적 성과로 평가 받을 부분이라는 입장이다. 반면 한계론은 새마을 운동의 '성공'에는 당 시 한국 농촌공동체에 부재했던 거버넌스에서 기인한다는 것이다. 즉 거버넌스의 부재로 인해 하향식 국가동원이 무비판 적으로 관철될 수 있었으며, 경제지수 향상으로 표현되는 “발전’이라는 가치에 대한 무비판적 수용이 가능했다는 것이다 (김성규 2013). 


\section{3. 새마을 운동 ODA 사업모델 형성과 평가 틀}

새마을 운동 $\mathrm{ODA}$ 가 관련 공여기관, 국제기구 그리고 개도국에서 보다 큰 공감대를 얻고, 더 나아가 세계적인 지역공동체개발 패러다임으로 자리 잡기 위해서는 사회적 자본 축적의 관 점과 거버넌스 형성 관점을 바탕으로 한 내부 동학의 규명 작업이 필요하다.

사회적 자본은 신뢰, 참여, 연계(network), 사회적 규범 혹은 제도역량, 이타주의 등을 그 요소로 하고 있으며, 또한 금융자본, 물리적 자본(인프라 등), 인적 자본 등 자본의 소유의 관 점에서 접근하는 것을 지양하고 자본의 활용의 관점에서 접근하고 있다. 사회적 자본은 그 속 성상 '축적'되며, 축적의 정도를 나타내는 지표와 새마을 운동 성과지표는 연관된다고 볼 수 있다. 사회적 자본의 개념요소와 표현인자는 지역사회의 특성에 따라 달리 정의되고 표현될 수 있지만, 일반적으로 사회적 자본이 새마을 운동의 성과평가 틀로 준용되기 위해서는 첫째, 사회적 자본과 새마을 운동의 궁극적 지향점이 상호 일치하는 부분이 있어야 하며, 둘째, 사회 적 자본의 개념요소가 새마을 운동의 과정을 통해 어떠한 변화와 발전을 보이고 있는지 감지 하고 비교할 수 있어야 한다.

〈표 1〉사회적 자본 관점에서의 새마을운동 성과평가의 틀

\begin{tabular}{c|c|c}
\hline 개념요소 & 표현인자 & 기능 \\
\hline 신뢰 & 협상, 의사소통, 거래 관계에서 신뢰 정도 & 공감대, 공통기반 조성 \\
\hline 참여 & 지역사회 행사 참여정도 & 공동의 목표 설정 \\
\hline 연계망(네트워크) & 지원체계의 구비정도 & 이웃과 지역사회 유지 \\
\hline 제도 및 규범 & 사회적 규범 형성 정도 & 자원동원, 안전망 확보 \\
\hline 이타주의 & 공동체 내 빈곤 감소 노력 정도 & 지역 공동 이익 창출 \\
\hline
\end{tabular}

출처 : 저자 재구성, 자료 : 소진광, 정갑진, 임형백, $2011: 64$

새마을 운동의 성과라고 언급되는 마을 공동체의 형성, 더불어 잘 사는 지역사회건설, 내부 역량 강화를 통한 공동번영 등은 사회적 자본을 축적하여 도모할 수 있는 가치에 해당한다. 즉, 이러한 관점에서는 새마을 운동이 지향하고 있는 목표는 사회적 자본의 기능과 긴밀히 연 계되어 있고, 이들 기능은 '사회적 자본의 개념요소가 표현인자를 통해 발현 되는 성과'라고 할 수 있다. 또한 새마을 운동 $\mathrm{ODA}$ 는 사업 과정 중에 지역사회 거버넌스 형성을 가져온다는 
점이다. 이는 개도국에서 보여 지는 전형적인 지배특성인 '통치'에서 다자간 협상이 중시되는 '거버넌스' 체제로의 전환을 의미한다. 새마을 운동이 그 과정에서 지향하고자 하는 바는 궁극 적으로 정부의 일방적인 통치와는 구분되어야 한다. 운동의 효과성과 지속성을 위해 추진 조 직의 형태는 분산형태가 바람직하며, 운동의 확산과 지역공동체 거버넌스 구축의 측면에서 보 면, ‘지시와 통제'를 위한 전국단위의 중앙 집중화된 사업본부 구축은 그리 바람직하다고 볼 수 없다. 운동을 주도하는 층은 운동의 초기 단계에서 정부와 공무원의 개입과 지도가 중요할 수 있지만, 차츰 운동의 주도는 지역 공동체 모든 이해당사자가 수행해야만 한다. 또한 조직의 가치 측면에서 보면 국가의 통치는 전통적인 의미의 '자본 축적을 통한 경제발전'을 지향하고 있는 반면, 새마을 운동은 궁극적으로 '사회적 자본의 축적'을 지향하고 있다. 조직의 공동목 표라는 측면에서도 통치는 강력한 국가의 형성을 목표로 하지만 거버넌스는 다양한 사회 성원 의 이해대변과 이해관계그룹의 형성, 궁극적으로는 시민사회의 구축을 지향한다.

추진방식의 측면에서도 새마을 운동이 지향하는 거버넌스는 통치와 구분되는 몇 가지 특징 을 가지는데, 권한 행사와 의사결정 방식이 다수결에 근거한 일방적 지시와 통제, 모든 이해당 사자의 '권한 공유'와 '역할에 따른 다자간 협상'원리에 따른다. 즉, 거버넌스는 다수결의 원칙 에 입각한 신속한 의사결정 보다는 공동체 내에서 맡은 역할에 따라 성원, 그룹 간 협상 과정 을 중시한다. 또한 공공재 생산관련 거버넌스 개념 중 특징적인 것은 공공재 생산관련, 공동체 성원은 공공재의 공동 생산자이며 동시에 소비자로 설정된다는 점이다. 즉 지역공동체 성원이 스스로가 창출한 공공재, 공공서비스로부터 ‘소외’받지 않는 상태를 지향 한다7).

7) 최근 부상하고 있는 글로벌 새마을 운동의 성공적 전개를 위해서는 새마을 운동을 세계인이 공유할 수 있는 가치체계로 설명할 필요가 있다는 문제의식이 공유되고 있다. 관련 연구의 목적은 새마을 운동의 실천적 과정에서 잠재되어 있던 사 회적 자본을 추출, 지역사회 단위에서의 거버넌스 형태와 그 특성을 밝히며, 이를 통해 미래의 새마을 운동의 발전적 정 책방향을 제시하고자 함이다. 임경수(2012) 등은 연구를 통해 새마을 운동의 성공에는 '시대적 압박'이라는 요인 외 한국 마을단위의 성원 간 신뢰와 참여 전통, 두레 품앗이 같은 협업의 전통, 그리고 농촌사회의 일상적인 대면 네트워크 등 이미 공동체 내부에 내재해 있는 사회적 자본이라는 요소를 주목하고 있다. 이러한 내재적 전통 속에서 근면, 자조, 협동 의 정신이 더해져 그 가치는 현재까지 유전되고 학습되어 왔다는 것이다. 한편 손혁상(2008) 등은 새마을 운동의 국제개 발협력사업화 모색을 언급하면서, 권리에 기반 한 접근(Rights-based approach : RBA)이라는 새마을 개발협력모델을 제시한다. 개도국 현지상황과 동떨어진 한국적 개발모델의 전수가 아닌, 개도국 지역공동체의 자기역량강화와 권리확보 를 통해 삶의 질을 변화시키는 공동체 내부 노력과 한국의 개발경험을 접목시킴으로써 보편적 개발모델화가 가능하다고 언급한다. 이러한 논의도 큰 틀에서 보면, 공동체 내부의 사회적 자본 축적과 권리의식, 주인의식을 바탕으로 한 거버넌 스 형성 논의와 무관하지 않다. 


\section{4. 개도국 새마을 운동 ODA 사업사례 분석}

\section{1 새마을 운동 ODA 사업 현황과 시사점}

91년 이후 수행되었던 새마을 운동 ODA 사업은 몇 가지 특징을 가지고 있다. 첫째, KOICA 는 다양한 프로젝트 사업을 추진해왔으며, 그 외 기관은 기관 특성에 맞는 사업에 집중해서 수 행하는 경향을 보여 왔다. 둘째, 진행된 사업이 특정 지역을 대상으로 장기적, 입체적, 유기적 으로 수행되지 못했다. 셋째, KOICA와 $\mathrm{EDCF}$ 를 제외하곤 지속적인 모니터링과 사후 평가 작 업이 제대로 수행되지 못했다. 넷째, 지자체 포함 새마을 운동 사업을 수행하는 기관은 다수 있으나, 관련 부처 간, 기관 간 협의나 공동 전략은 부재했다는 점 등이다.

이를 바탕으로 향후 새마을 운동 $\mathrm{ODA}$ 사업 추진 전략형성을 위한 시사점을 정리하면 다음 과 같다. 첫째, 새마을 운동의 글로벌 사업 표준 모델 형성과 현지화 작업이 필요 하다. 사업 대상지의 기후, 문화, 관습과 제도 등을 고려한 사전 사업 설계가 중요하며, 수원국의 소득수 준과 발전 지표에 맞는 지원이 아울러 필요하다. 즉, 중국, 필리핀 등 개발사업의 성과가 있는 국가 대상으로는 역량개발과 컨설팅 위주의 사업을 적용하는 등 국별 차별화 전략이 합리적이 다. 둘째, 장기적 관점을 가지고 새마을 운동 $\mathrm{ODA}$ 의 표준화된 단계 설정이 필요하며, 표준화 된 단계는 다시 현지의 상황과 발전정도에 맞게 유연하게 조정되어야 한다. 표준화된 단계설 정을 위해서는 사전 가이드라인 설정과 매뉴얼화가 필수인데, 이를 위해서 수행된 사업의 분 석을 통한 기관과 사업을 아우르는 통합매뉴얼 작성, ODA의 성과 지향적 관리(managing for result) 시스템구축, 사업 전·후방 연계효과(linkage effect)까지 고려한 지표의 개발 등이 필 요하다(임형백, $2011: 123$ ). 셋째, 관련 지원 사업의 유기적 연계, 입체적, 맞춤형 지원이 필 요하다. 예를 들어 개도국 농촌 개발 사업은 도시화(마을 만들기), 거버넌스 형성 지원 사업과 연계될 수 있으며, 내용적으로 교육, 직업훈련, 젠더, 보건, 환경 등 관련 사업의 요소를 결합 시킬 수 있다. 지역공동체개발 사업이 개발협력에서 중요한 부분을 차지하고 또한 강점을 가 질 수 있는 것도 이러한 사업 연계성과 포괄성에 있다 하겠다. 또한 연계성과 포괄성은 사업의 지속가능성에 중요한 전제이며, 지역공동체의 지속가능하며 포괄적인 발전(sustainable and inclusive development)에 기여한다. 넷째, 지역 주민, 특히 빈곤층의 참여를 극대화 시킬 수 있는 초기 수익사업 형성, 지원이 필요하다. 이는 개도국 빈곤층 주민들이 생존을 위한 단기적 경제활동 등으로 공동체 사업에 참여할 수 없는 현실적 상황에서 기인한다. 그런데 농업이 해 당 개도국의 주력 산업이라 해도 수익 사업의 내용이 반드시 농업과 관련될 필요는 없다. 즉, 
마을 공동 수익사업은 농업, 임업, 축산업, 가내 수공업 부문 뿐 만 아니라, 현지 공동체의 상 황과 변화된 시대에 맞게 ICT, 유통, 금융 부문에도 형성될 수 있다. 다섯째, 사업 예산 낭비, 사업대상지와 연수생의 중복 등을 막고 생산적 정보와 노하우를 공유하기 위해서는 사업 수행 관련 기관, 부처 간 연계와 포괄적 조정이 필요하다. 연계와 조정을 위한 한시적인 독립 $\mathrm{TF}$ 나 기구 구성도 고려할 수 있다. 기구는 먼저 각 기관에서 시행하고 있는 사업의 정보를 파악하 고, 조정을 통해 중복투자를 피하고, 선택과 집중을 통해 보다 높은 사업의 효율성과 지속 가 능성을 추구해 나가야 할 것이다. 여섯째, 상시적인 모니터링과 사후 평가, 관리 작업은 새마 을 운동 사업 성공과 노하우 축적에 관건이 되는 사업인바, 이를 강화해야 한다. 현재 $\mathrm{KOICA}$ 와 $\mathrm{EDCF}$ 등을 제외하면 해당 사업 모니터링 및 사후 평가 부문은 제대로 이루어지고 있다고 보기 어려우며, 이는 사업의 부실과 예산 낭비로 이어질 우려가 있다는 점에서도 지적되어야 할 부문이다. 따라서 이러한 문제점을 해결하기 위해서는, 각 공여기관, 관계 부처가 전문 인 력과 예산확보를 통해 이를 강화하는 방법과 독립적인 사업별 상시 모니터링 시스템, 사후 평 가 프로그램의 가동도 모색해 볼 만 한다.

\section{2 지자체와 $\mathrm{KOICA}$ 사업사례 분석}

사례는 '몽골 나날이흐군 알타이마을 새마을운동 시범사업'과 미얀마 흘레구 지역 농촌개발 사업“이며, 경제적 자본과 사회적 자본 축적의 관점에서 분석, 정리했다. 경제적 자본의 축적 관련 지표는 (1) 수익 사업의 형성 여부, (2) 경제 시스템 구축 정도, (3) 물적 인프라 구축 정도 등을 꼽을 수 있다. 사회적 자본축적 관련 지표는 (1) 거버넌스 형성 정도, (2) 동기부여와 의식 고취(새마을 정신 함양) 정도 등을 설정했다. 각 지표의 세부 내용을 정리하면 다음과 같다.

\section{〈표 2〉 지역공동체 개발사업의 경제적, 사회적 자본}

\begin{tabular}{c|c|l}
\hline \multirow{4}{*}{$\begin{array}{c}\text { 경제적 } \\
\text { 자본 }\end{array}$} & $\begin{array}{c}\text { 물적 인프라 } \\
\text { 구축 }\end{array}$ & $\begin{array}{l}\text { 주거환경개선(마을도로개선, 용수로정비, 주택개량, 전기 공 } \\
\text { 급, 상수도 개발, 우물, 저수조 설치, 부억, 화장실 개량 등) } \\
\text { 학교 보수 및 신축, 학습 기자재 제공, } \\
\text { 다리 건설, 마을회관 건립 }\end{array}$ \\
\cline { 2 - 3 } & $\begin{array}{c}\text { 경제 시스템 } \\
\text { 구축 }\end{array}$ & 소액 금융제도(micro finance) 활성화 정도 \\
\cline { 2 - 3 } & $\begin{array}{c}\text { 수익사업 형성 } \\
\text { 려, 생산성 향상을 위한 농기계 지원과 사용, 수리 기술 전수 }\end{array}$ \\
\hline
\end{tabular}




\begin{tabular}{c|l|l}
\hline \multirow{3}{*}{$\begin{array}{c}\text { 사회적 } \\
\text { 자본 }\end{array}$} & $\begin{array}{l}\text { 주민조직 활성화(마을 청년, 부녀회 활성화, 형성프라 관리 위 } \\
\text { 원회 운영), 마을 발전 관련 위원회 결성, 마을 주민 간 화합, } \\
\text { 지방 정부와의 유기적 협력관계 }\end{array}$ \\
\cline { 2 - 3 } & $\begin{array}{l}\text { 동기부여와 } \\
\text { 의식고취 }\end{array}$ & $\begin{array}{l}\text { 지역공동체, 농업 개발, 새마을 운동 관련 연수·교육 활성화, } \\
\text { 새마을 정신 함양 }\end{array}$ \\
\hline
\end{tabular}

출처 : 저자 작성

\subsection{1 사업 개요와 형성 배경}

몽골의 해당 사업은 2005년 새마을 중앙운동본부 산하 경기도새마을회의 지원으로 시작되 었으며, 이후 2008년까지 4년간 실시되었다. 사업 대상지는 수도 울란바타르에서 $40 \mathrm{~km}$ 떨어 진 나날이흐군 알타이 10,11 마을이며, 이 마을은 수도의 외곽에 형성되고 있는 전형적인 몽 골 빈민 마을 중의 하나이다. 마을은 마을규모, 밀집성, 도시의 접근성 등을 고려해 볼 때 사 업지로 적합했으며, 무엇보다 도시화에 따른 빈곤 심화 지역으로 빈곤 감소라는 뚜렷한 목표 를 설정할 수 있다는 점 또한 새마을 운동 사업 지원 지역으로 선정된 주요 이유였다.

사업대상지 선정은 2004년 해당 지자체의 새마을회와 부녀회 임원들의 '몽골 지원 사업을 위한 사전 조사' 방문 시 해당 지역 활동가와의 만남으로 시작되었다. 사전조사팀은 애초 목축 지원을 통한 소득증대사업을 계획하고 있었으나, 현지 대사관, KOICA 사무소 등과의 면담 끝 에 해당 사업의 현실적 어려움을 감안, 빈민 마을을 선정하여 '새마을운동 시범사업 형성'에 집중하기로 결정했다.

당시 나날이흐군은 6 개면으로 이루어져 있었으며, 전체 인구는 2 만 3 천여 명이었다. 특징적 인 것은 6 개면 중 5 개 지역이 목축에 적합한 이동가옥의 형태가 주를 이루는 이른바 '게르지 역'으로 안정된 주거지의 형태를 갖추고 있지 않았다는 점이다. 군 전체 사회인프라 현황을 보 면, 초중고가 5 개, 공식적인 병원 1 개, 유치원 1 개로 교육, 보건, 생활환경은 매우 열악했다. 그 중 사업지로 선정된 알타이 10,11 마을의 전체 인구는 총 3 천여 명이었으며, 대부분 가정 이 목축을 통해 생계를 유지하고 있었다. 사업이 집중되었던 11 마을의 경우 240 가구 1000 여 명이 거주하는 비교적 규모가 작은 마을이었다. 
〈표 3〉나날이흐 군 알타이 10,11 마을 개요

\begin{tabular}{c|c|c|c|c}
\hline 단위 & 인구 & 종사업 & 주거형태 & 학교, 병원 등 \\
\hline 나날이흐 군 & 23,000 & 목축, 광업 & 게르 & 초중고 5곳, 병원1 \\
\hline 알타이 10-11마을 & 3,000 & 목축 & 게르+간이주택 & $\begin{array}{c}\text { 학교(통합과정) } 1, \\
\text { 병원 없음 }\end{array}$ \\
\hline
\end{tabular}

출처 : 저자 작성

몽골의 새마을운동 사업은 공식적으로는 경기도 새마을회가 처음 시작했으며, 당시 몽골 지 역주민들의 새마을 운동에 대한 지식과 경험은 전무 했다고 보고되고 있다. 사업 형성 당시 몽 골 중앙 정부는 물론이고 사업대상지인 나날이흐군 지방 공무원과 주민들의 새마을 운동에 대 한 이해도는 매우 낮았으며, 따라서 호응 또한 높지 않았다. 이후 한국의 새마을 운동 중앙회 의 활발한 몽골 지도자 초청 연수 활동 등을 통해 몽골 현지에 새마을회가 조직되기 시작했으 며, 몽골은 해외에서 새마을 지도자대회를 개최한 최초 국가로 기록되고 있다8). 현재 전국적 으로 새마을회가 구성되어 있으며, 울란바타르의 새마을 중앙회는 정부로부터 토지를 무상으 로 임대 받아 자체 새마을 연구원 건립계획도 수립하고 있는 등 새마을회가 외형적으로는 단 기간에 많은 발전을 이루었다고 평가된다.

한편, 경기도 새마을회는 해당 새마을운동 시범마을 운영 사업을 '기반조성단계'와 '자립완 성단계'로 나누어 사업을 진행했는데, 기반조성단계의 사업은 주로 마을 공동 환경개선사업, 소규모 시범소득사업 형성, 주민의식고취와 새마을 정신 함양에 주력했으며, 자립완성단계에 는 사업지역의 수익사업 형성을 위해 집중 투자하는 전략을 취했다.

미얀마 사업은 미얀마 정부의 정책과 관련을 가진다. 미얀마 정부는 농촌개발과 빈곤퇴치를 가장 높은 우선순위로 설정하고 있었으며9), 해당 사업은 '농업과 농촌개발을 통한 빈곤 완화' 를 목표로 하고 있다는 점에서 미얀마 국가 정책과 부합하고 있다. 사업이 형성될 2008년 당 시 미얀마의 총 인구는 약 5 천 800 만 명이었으며 이 중 농촌 인구는 $70 \%$ 에 육박하는 등 절대 다수를 차지했다. 또한 2009년 기준 농업부문은 미얀마 총 GDP의 $39.9 \%$ 를 차지하고 있었으 며, 이는 농업이 미얀마 경제에 가장 중요한 산업이라는 점을 말해주고 있었다. 따라서 미얀마

8) 한국 지자체의 몽골 지원 선호 요인으로는 (1) 2000년대 초반 이후 대 몽골 지원 분위기 고조, (2) 지리적 인접성, (3) 문 화적 공감대, (4) 몽골 현지 지방정부와의 사업 협약, 추진의 용이성, (5) 몽골 지방 공무원의 높은 새마을 연수(교육)과정 참여 의지 등을 꼽을 수 있다.

9) 미얀마 정부는 4차 경제개발 5개년계획(Fourth Short-term 5 year Plan, 2006-2007, 2010-2011)과 종합농촌개발계 획(Integrated Rural Development Plan)을 통해 미얀마 경제발전을 위해서는 농촌개발이 중요함을 강조하고 있으며 농촌개발을 통한 빈곤 완화를 가장 중요한 정책과제로 설정하고 있다. 
의 경제성장과 빈곤퇴치를 위해서는 농업발전과 농촌개발이 그 무엇보다도 우선적으로 이루어 져야 할 부문이며, 농업과 농촌 발전을 지향하는 해당 사업은 미얀마 지역공동체 발전과 더 나 아가 국가 경제 발전과 매우 긴밀한 연관성을 가진다고 평가할 수 있다.

이러한 사회경제적 배경 하에 해당 사업은 $\mathrm{KOICA}$ 농촌개발사업의 일환으로 2009년 11월에 시작되어 2 년간 수행되었다. 미얀마 정부는 “미얀마 흘레구지역 농촌개발사업의 제안요청서” 를 통해 양곤 주 흘레구 타운의 5 개 마을에 대한 개발 원조를 요청하였으며, 이후 협의와 조정 과정을 거쳐 양곤주 흘레구(Hlegu) Township 소재지로 부터 약 $2.5 \mathrm{~km}$ 떨어진 사칸지(Sa Khan Gyi) 마을, $4 \mathrm{~km}$ 떨어진 케양(Kha Yaung) 마을, 그리고 약 $8 \mathrm{~km}$ 떨어진 차우커딘 (Kyauk Kha Din) 마을을 지원 대상지로 최종 선정하였다10).

2008년 선정 당시 사업 대상지 마을의 주택, 가구, 인구수 등 마을 현황을 보면 다음과 같다.

\section{〈표 4〉흘레구 지역 및 사업대상 마을 현황}

(2008년)

\begin{tabular}{c|c|c|c|c|c}
\hline \multirow{2}{*}{ 마을명칭 } & $\begin{array}{c}\text { 주택수 } \\
\text { (호) }\end{array}$ & \multirow{2}{*}{ 가구수 } & \multicolumn{3}{|c}{ 인구수 } \\
\cline { 4 - 6 } & & 110 & 남 & 여 & 계 \\
\hline 케양 & 86 & 4247 & 229 & 476 \\
\hline 사칸지 & 414 & 423 & 905 & 938 & 1,843 \\
\hline 차우커딘 & 427 & 463 & 892 & 975 & 1,867 \\
\hline 계 & 927 & 996 & 2,044 & 2,142 & 4,186 \\
\hline 흘레구 타운 & 37,834 & 40,962 & 89,471 & 93,772 & 183,243 \\
\hline
\end{tabular}

출처 : Hlegu Township DoA

선정된 세 마을은 규모와 직업분포도, 소득의 측면에서 각기 다른 특징을 보여주고 있었다. 케양 마을의 규모가 가장 작으며, 주거는 밀집되어 있다. 또한 거의 모든 가구는 농업에 종사 하고 있으며, 단 4 가구 만이 가축사육과 농업을 병행하고 있다. 차우커딘11)과 사칸지 마을의

10) 흘레구 타운은 총 56개의 마을(village)로 구성되어 있으며, 2012-13년 현재 인구는 약 221,000 명, 마을 주민의 대부 분은 논농사쌀농사)에 종사하고 있으며, 쌀농사를 하면서 동시에 원예, 양계 양돈 등에 종사 하고 있다.

11) 차우커딘 마을은 실제로는 차우커딘(Kyak Kha Din) 마을, 카띳(Ka Dit) 마을, 예카띳(Ye Ka Dit) 마을, 캄마내잇밴(Ka Mar Nate Ban) 마을로 구분되며 이 중 차우커딘 마을의 규모가 230호 가량으로 가장 커서 통상 이 지역 마을을 아우 르는 명칭이 되었다. 
규모는 비슷했으며, 농업에 종사하는 가구가 절대적으로 많으나, 양곤지역의 서비스 업종 종 사, 자영업 종사자들이 있었다. 특히 사칸지 지역은 인근에 세워진 공장에서 일하며 소득을 올 리는 사람들도 있었다. 사업대상 마을의 선정 당시 소득 수준을 보면, 케양 마을이 가장 빈곤 한 지역이었으며, 사칸지 마을은 가장 소득 수준이 높은 마을이었다. 하지만 사칸지는 마을 주 민 간 빈부의 격차가 가장 심한 마을이기도 했다.

\subsection{2 몽골 나날이흐군 알타이마을 새마을운동 시범사업}

몽골 사업은 한국 지자체의 지원예산 규모에 맞는 병렬적, 단발성 사업의 형태를 띠었다는 단점도 있지만, 한 지역에 2004년부터 8년간 사업을 수행 했다는 점은 사업의 지속성과 사후 관리 측면에서 의미를 부여할 수 있다.

\section{(1) 경제적 자본의 형성 측면}

대표적인 물적 인프라사업은 마을 공동우물건립, 마을회관건립, 다리 건설 등이며, 수익사 업은 공동 농장(채소밭)운영사업을 꼽을 수 있다. 한편 몽골사업에서 경제시스템 구축은 상대 적으로 미약했다.

우물사업의 경우 이용가구수가 초기 46가구에서 2007년말 90가구로 증가했다는 점, 새마을 회관의 운영의 경우, 이용주민수가 2005년 500명 이하에서 2007년 말 700명 이상으로 증가 했다는 점은 마을 주민의 사업에 대한 관심도와 참여도 증가라는 측면에서 의미가 있다. 특히 마을 회관 내 도서관 이용객 증가와 이에 따른 회관 경비원와 도서관 관리인 각 1 명씩을 두어 관리에 힘쓰고 있는 점도 주목된다.

수익사업인 공동농장은 소액이긴 하나 순이익이 점차 증가하고 있다는 점은 긍정적이며, 기 타 젖소목장, 강화양모 사업, 벽돌공장, 재봉틀 구입을 통한 가내 자영업자 육성 사업의 경우 소규모이긴 하나 지역사회 고용창출에 기여하고 있다고 평가할 수 있다.

\section{(2) 사회적 자본의 형성 측면}

2004년 경기도 새마을회의 나날이흐군 알타이 10, 11 마을 지원을 시작으로, 몽골 새마을 운동 사업은 한국의 많은 지자체로부터 꾸준한 관심과 지원을 받고 있다. 현재 몽골 25 개 주 
중 18 개 주에 새마을 운동 본부가 조직되어 있을 정도로 새마을 운동에 대한 인지도는 비교적 높다. 이러한 중앙 조직 형성은 향후 사업 확대에 있어 주요한 자산임에 틀림없다.

하지만 지역단위의 조직과 주민의식은 여전히 취약하며, 새마을 운동을 돈 주는 원조의 한 형태로 이해한 초기 이해 수준에서는 탈피했지만, 여전히 새마을 운동을 통한 지역 공동체 거 버넌스 형성 정도는 높지 않다고 판단된다. 특히 새마을 운동이 자발성에 기반한 운동이라는 점에 대한 주민의 이해도는 낮은 상태이다. 몽골 주민의 낮은 결집력, 상호 부조의 전통이 부 재한 환경도 낮은 거버넌스 형성의 한 요인이다. 이러한 환경은 초기 우물사업, 마을회관 건립 등 마을 현안에 대한 이견과 갈등으로 표출되었다. 또한 해당 마을 절대 빈곤층은 당장의 생계 유지를 위한 경제활동으로 운동에 참여하기 어려운 상황이며, 이러한 요인들로 인해 현재 마 을 공동 사업에 대한 참여율은 $20 \%$ 내외로 판단되고 있다.

한편, 몽골 사회 전체의 새마을 운동에 대한 높은 인지도에도 불구하고 지방정부 공무원들 의 해당 사업에 대한 시각과 새마을 운동 정신에 대한 이해의 폭은 넓지 않았으며, 여전히 현 물 원조·투자를 선호하였다. 사업을 통해 몽골에 새마을 운동의 이미지와 정신을 직접 전달하 며, 이를 통해 몽골 새마을회의 조직, 지도자의 발굴 등은 성과로 보이지만, 마을 공동체에서 의 새마을 운동에 대한 공감도와 스스로의 동기부여까지는 미치지 못한 것으로 보인다. 또한 새마을회의 조직, 현지 지도자의 발굴은 한국의 새마을 중앙회의 개도국 새마을 지도자 연수 의 성과로 보이지만, 몽골의 경우 연수 대상이 한정되며 반복연수 참여 등 운영상의 오류가 존 재했다. 또한 새마을 운동에는 지속성과 확산성을 저해하는 몽골의 정치, 사회구조적인 여건 이 존재한다. 예를 들어 몽골은 지방선거 결과에 따라 실무 공무원까지 모두 교체되는 공직 사 회 구조가 전임자가 형성해 놓은 지역 사업이 백지화 되는 등 사업의 지속성을 방해하고 있었다.

결국 해당 사업수행 주체는 사업 대상지를 좁게 한정하여 집중 지원과 시범 사업 운영으로 효과성을 제고하고, 빈곤퇴치와 마을 주민 수익 증대 등의 사업의 성과를 인근 마을로 확산시 키고자 했으며, 이러한 의도는 긍정적으로 평가된다. 한편, 사업의 효과성과 지속가능성을 저 해하는 정치·경제적 제약요건 또한 강하게 존재했다. 여기에 낮은 지역 거버넌스 형성 정도, 중앙과 지방 정부 간 유기적인 사업 협조 체제가 구축되어 있지 못한 것도 사업 확산을 저해하 는 요인으로 보였다. 향후 한국 지자체의 사업 수행은 이러한 제약요건 완화와 지역 거버넌스 형성에 일차적으로 주력해야 하며, 동시에 마을의 절대적 빈곤층 자발적 참여를 유도할 수 있 는 사회적·경제적 동기부여 프로그램 마련에 주력해야할 것으로 판단되었다. 


\subsection{3 미얀마 흘레구 지역 농촌개발 지원 사업}

\section{(1) 경제적 자본의 형성 측면}

물적 인프라 구축사업에 해당되는 마을 도로 개선, 지붕 개량 및 상수도 개선사업, 3 개 마을 회관 신축, 1 개 학교 신축 및 1 개 학교 개보수, 교량 건설(1개 신설, 1 개 개보수), 그리고 미얀마 정부가 담당하기로 한 전기공급 등은 원활히 이행되었다는 측면에서 긍정적인 평가를 내릴 수 있다. 문제는 사후 관리인데, 각 마을 별로 물적 인프라 관리에 대한 평가는 엇갈릴 수 있다.

마을 도로 개선 사업의 경우, 케양 마을의 경우 인프라 관리 위원회의 유지 보수 활동이 눈 에 띤 반면 사칸지 마을의 경우 우기에는 물웅덩이가 도로 곳곳에 형성되고 있는 등 관리가 눈 에 띄게 소홀했다. 또한 사칸지 마을에 건립된 폭 $28 \mathrm{~m}$ 교량의 사후 관리와 관련해서는, 오른 쪽 강안이 빠르게 침식되고 있어 강둑을 다지는 작업이 필요해 보였으나 이를 위한 주민의 자 체 노력은 없었다. 사칸지 마을의 요청으로 인해 건설된 다리가 원거리 마을 주민들과 아이들 의 등곳길 등에 안전성과 편리함을 준 것은 사실이나 애초 의도했던 것처럼 지역 생산물 수송 의 편리성과 이를 통한 마을 소득증대로 이어지고 있는 근거는 확인되지 못했다. 또한 사칸지 마을에만 신축된 초등학교도 관리 상태가 양호하지 못했다. 결국 전체 사업의 규모에 비해 상 대적으로 많은 인프라 사업이 진행된 사칸지 마을의 경우 해당 사업의 효과성에 대해 의문이 제기될 수 있다.

한편 차우커딘 마을 회관 건립 사업의 경우, 회관은 각기 멀리 떨어진 3 개 작은 마을 460 여 가구 주민들의 접근성이 매우 취약했으며 마을 회관 본연의 기능을 수행하기에는 근본적인 한 계가 있었다. 애초 세 마을 모두 마을회관의 높은 활용도를 예상하였으나, 케양 마을 외 활용 도는 매우 낮은 것으로 조사되었고, 특히 마을회관에 설치된 진료소(clinic)와 주간탁아시설 (day care center)의 활용도는 현저히 낮았다.

경제 시스템 구축의 측면에서 3 개 마을의 소액금융 사업에 대한 평가는 중요하다. 이는 현 재 현지 공무원과 주민들이 추가 지원을 가장 원하고 있는 부문이기도 하다. 문제점으로는 수 요에 비해 재원의 부족함과 이로 인한 낮은 대출 금액, 높은 이자율과 지나친 담보 제공 조건 등을 꼽을 수 있다. 또한 마이크로 파이낸스 사무실의 금융회계 전문성 부족으로 자산과 부채 의 종합적인 회계정리 상태가 부실하다는 점도 지적될 수 있다. 이후 해당 사업 확대 시 충분 히 고려되어야 할 점이다. 마이크로 파이낸스 기금의 규모를 높이기 위해서 주민 스스로가 출 
자하는 방식에 대해서 고민할 수 있지만, 실제로는 이에 매우 소극적이어 지속가능성 측면에 서 제한성을 가지고 있다.

수익사업의 형성의 측면에서, 축산 시범단지 조성 사업은 KOICA에서 지원한 종돈사(1개 소), 비육돈사(3개소) 및 계사(3개소)를 그대로 사용하고 있었으며 사업 이후 개인 투자는 없 었다. 즉, 축산을 농가소득 증대의 한 방법으로 생각하고는 있지만 이를 위한 주민의 투자는 없었다는 측면에서 해당사업은 낮은 확산성을 보이고 있었다. 친환경 유기농 시범단지 조성 사업은 현지 토양과 기후에 맞는 작품 선정의 실패와 퇴비 형성에 대한 문화적 차이 등으로 인 해 정착되지 못했다. 또한 유기농 생산물은 해외 수출을 통한 수익창출로 이어져야 하는데, 미 얀마는 이러한 구조를 아직 갖고 있지 못한 점도 사업의 한계로 작용하고 있다.

\section{(2) 사회적 자본의 형성 측면}

사업초기 지역사회 거버넌스 형성 정도는 매우 취약했으며 미얀마 지방 공무원의 소극적인 참여, 경직된 행정체계, 전문가의 잦은 교체 등으로 사업 시기가 일부 지연되기도 하였다. 또 한 일부 마을의 경우 사업 시행과정 중에 마을 지도자의 부정이 있어 마을주민들의 단합을 크 게 저해하였다. 케양 마을의 경우 마을의 종교 지도자와 더불어 주민 간 원활한 소통과 주민 위원회의 구성 등 지역 주민들의 의식개혁은 상대적으로 보다 진전되었다. 이러한 거버넌스 형성의 차이는 실제 사업성과의 차이로 이어 졌는데, 사업 후 마을의 빈곤 경감에 대한 적절성 을 묻는 설문조사에서도 케양과 차우커딘 마을은 상대적으로 높게, 사칸지 마을은 상대적으로 낮게 나타났다. 이는 사칸지 마을주민 스스로가 해당사업이 마을의 빈곤 감소에 그리 큰 영향 을 주지 않았다고 생각하고 있음을 의미한다.

결론적으로 3 개 마을은 사업성과, 효과성, 지속성에 있어 현격한 차이를 나타내고 있었으 며, 세 지역 중 가장 규모가 작고 밀집되어 있으며, 가장 낮은 소득수준을 나타냈던 케양 마을 의 사업 효과성과 지속성이 가장 뛰어나다고 판단되었다. 한편 사업대상지로 선정 당시 마을 규모와 소득수준이 가장 높았으며, 마을 주민들이 농업 외 상업 등 다른 직업 종사들이 많은 지역인 사칸지 마을은 사업의 성과가 가장 낮다고 판단되었다. 이러한 차이는 지역 내 전통적 으로 형성되어 왔던 사회·경제적 자원의 차이가 사업성과에 영향을 미친 것으로 분석된다. 즉, (1) 사업 당시 각 마을 리더(이장, 종교지도자 등)의 역할(합리성과 공정성 측면), (2) 마을 규모 (인구학적 요인), (3) 경제 수준의 차이, (4) 원조에 대한 마을 주민의 의식의 차이 등에서 기인 했다고 볼 수 있다. 
〈표 5〉마을의 빈곤 경감에 대한 적절성

\begin{tabular}{|c|c|c|c|c|c|c|c|c|c|}
\hline \multicolumn{10}{|c|}{ 마을의 빈곤 경감에 대한 적절성 } \\
\hline \multicolumn{2}{|c|}{ 구분 } & $\begin{array}{l}\text { 매우 } \\
\text { 낮음 }\end{array}$ & 낮음 & 중간 & 높음 & $\begin{array}{l}\text { 매우 } \\
\text { 높음 }\end{array}$ & 계 & 평균 & $\begin{array}{l}\text { 표준 } \\
\text { 편차 }\end{array}$ \\
\hline \multirow{2}{*}{$\begin{array}{l}\text { Kha } \\
\text { Yaung }\end{array}$} & 빈도 & 0 & 1 & 6 & 15 & 0 & 22 & 3.64 & 0.57 \\
\hline & 비중(\%) & 0.0 & 4.5 & 27.3 & 68.2 & 0.0 & 100.0 & & \\
\hline \multirow{2}{*}{$\begin{array}{c}\text { Sa Khan } \\
\text { Gyi }\end{array}$} & 빈도 & 2 & 2 & 15 & 5 & 0 & 24 & 2.96 & 0.79 \\
\hline & 비중(\%) & 8.3 & 8.3 & 62.5 & 20.8 & 0.0 & 100.0 & & \\
\hline \multirow{2}{*}{$\begin{array}{l}\text { Kyauk } \\
\text { Ka Din }\end{array}$} & 빈도 & 0 & 0 & 6 & 15 & 6 & 27 & 4.00 & 0.67 \\
\hline & 비중(\%) & 0.0 & 0.0 & 22.2 & 55.6 & 22.2 & 100.0 & & \\
\hline \multirow{2}{*}{ 계 } & 빈도 & 2 & 3 & 27 & 35 & 6 & 73 & 3.55 & 0.81 \\
\hline & 비중(\%) & 2.7 & 4.1 & 37.0 & 47.9 & 8.2 & 100.0 & & \\
\hline
\end{tabular}

주 : 평균, 표준편차는 각 답변(매우 낮음 매우 높음)마다 이산 확률 변수(1 5)를 부여하여 도출한 것임.

출처 : Self-evaluation of Hlegu Township Agricultural and Rural Development Program, 2011

\section{2 .4 사업 비교}

몽골과 미얀마 지역공동체 개발 사례를 지원 성격, 주력 지원 부문 등 몇 가지 측면에서 비 교해보자 한다. 몽골 사업의 경우 지원 방식은 전형적인 하향식(top-down) 형태를 보이고 있 으며 미얀마의 경우 하향식 사업 형성 후 지역 활성화를 통한 자발적 사업 전개를 지향하고 있 었다. 지원의 성격 측면에서 보면, 몽골의 사업 방식이 병렬적 인프라 지원 사업이 먼저 형성 되고 이후 소규모 수익사업 형성 지원을 수행한 것에 비해, 미얀마는 '경제적, 사회적 요소의 맞춤형 지원'의 성격을 지닌다고 볼 수 있다. 주력 지원 부문을 보면, 몽골 사업은 마을 인프 라개선 사업 등 기반 조성 사업을 우선 과제로 설정하고 그 다음 단계에서 수익사업형성 지원 을 꾀했다면, 미얀마 사업은 마을 인프라 개선사업에 주력하면서도 농업생산력 향상을 위한 기술전수, 건축기술전수, 수익사업 형성, 더 나아가 거버넌스 형성 사업까지 동시에 병행한 사 례라고 할 수 있다.

사업의 확대가능성은 지원 주체의 의지와 지원 규모, 사회적, 경제적 측면을 통합적으로 고 려하는 맞춤형 지원여부, 지원이 장기적 개발 계획 하에서 이루어지고 있는지 여부, 마을 단위 의 자발성과 동기부여 정도 등과 매우 밀접히 맞물려 있다. 이러한 잣대로 평가를 할 때 미얀 마 사업의 경우 특정 마을에서 그 확산성과 발전 가능성을 확인할 수 있었다. 
〈표 6〉 몽골 나날이흐 군과 미얀마 흘레구 타운 사업의 비교

\begin{tabular}{c|c|c|c|c}
\hline 사업 & 지원 방법 & 지원성격 & 지원 부문 & 주력 부문 \\
\hline 몽골 & 하향식 & $\begin{array}{c}\text { 병렬적 인프라 사업 } \\
+ \text { 수익사업형성 지원 }\end{array}$ & $\begin{array}{c}\text { 마을회관, 우물, } \\
\text { 마을 길 정비, } \\
\text { 수익사업(소규모) }\end{array}$ & $\begin{array}{c}\text { 마을인프라개선 } \\
+ \text { 수익사업형성 }\end{array}$ \\
\hline 미얀마 & $\begin{array}{c}\text { 하향식 } \\
+ \text { 지역 활성화 }\end{array}$ & $\begin{array}{c}\text { 경제적, 사회적 } \\
\text { 통합적 지원 }\end{array}$ & $\begin{array}{c}\text { 마을 회관, 학교, } \\
\text { 교량, 마을 } \\
\text { 거버넌스 형성 } \\
\text { 지원 }\end{array}$ & $\begin{array}{c}\text { 마을인프라 개선 } \\
+ \text { +수익사업형성 } \\
+ \text { +농업, 건축 기술전수 } \\
+ \text { 거버넌스 형성 }\end{array}$ \\
\hline
\end{tabular}

출처 : 저자 작성

〈표 7〉 미얀마 사업 평가결과 : 마을 발전에 대한 파급효과

\begin{tabular}{c|c|r|r|r|r|r|r|r|r}
\hline \multicolumn{2}{c|}{ 구분 } & $\begin{array}{c}\text { 매우 } \\
\text { 낮음 }\end{array}$ & 낮음 & 중간 & 높음 & $\begin{array}{l}\text { 매우 } \\
\text { 높음 }\end{array}$ & 계 & 평균 & $\begin{array}{c}\text { 표준 } \\
\text { 편차 }\end{array}$ \\
\hline \multirow{2}{*}{$\begin{array}{c}\text { Kha } \\
\text { Yaung }\end{array}$} & 빈도 & 0 & 0 & 2 & 17 & 3 & 22 & 4.05 & 0.47 \\
\cline { 2 - 11 } & 비중(\%) & 0.0 & 0.0 & 9.1 & 77.3 & 13.6 & 100.0 & & \\
\hline \multirow{2}{*}{$\begin{array}{c}\text { Sa Khan } \\
\text { Gyi }\end{array}$} & 빈도 & 0 & 1 & 14 & 6 & 1 & 22 & 3.32 & 0.63 \\
\cline { 2 - 11 } & 비중(\%) & 0.0 & 4.5 & 63.6 & 27.3 & 4.5 & 100.0 & & \\
\hline \multirow{2}{*}{$\begin{array}{l}\text { Kyauk } \\
\text { Ka Din }\end{array}$} & 빈도 & 0 & 0 & 6 & 16 & 4 & 26 & 3.92 & 0.62 \\
\cline { 2 - 11 } & 비중(\%) & 0.0 & 0.0 & 23.1 & 61.5 & 15.4 & 100.0 & & \\
\hline \multirow{2}{*}{ 계 } & 빈도 & 0 & 1 & 22 & 39 & 8 & 70 & 3.77 & 0.66 \\
\cline { 2 - 10 } & 비중(\%) & 0.0 & 1.4 & 31.4 & 55.7 & 11.4 & 100.0 & & \\
\hline
\end{tabular}

주 : 평균, 표준편차는 각 답변(매우 낮음 매우 높음)마다 이산확률변수(1 5)를 부여하여 도출한 것임.

출처: Self-evaluation of Hlegu Township Agricultural and Rural Development Program, 2011

또한 사업 평가를 통해서, 지원 사업지의 선택은 (1) 마을 규모의 적정성, (2) 마을 지도자의 자질과 청렴도, (3) 농업기반 공동체의 동질성 여부 등의 변수가 중요하게 고려되어야 함을 알 수 있었다. 아울러 사업의 효과성, 지속성, 확산성은 (1) 새마을 정신에 대한 마을 리더들의 공 감도와 (2) 리더에 대한 신뢰를 바탕으로 한 마을 주민의 자발적 동기부여 형성 정도, (3) 적절 한 수익 사업(양돈, 양계, 특용작물 등)의 형성 가능성, (4) 수익 사업 전반을 뒷받침해주는 '소 규모 마을 금융시스템'의 형성 등과 밀접한 관련을 가진다고 분석되었다. 


\section{5. 결론 : 새마을 운동 ODA 확대방안}

최근 논의는 새마을 운동 ODA 사업이 프로젝트 별로 고립·병렬적으로 형성되기 보다는, 농 촌개발(rural development)로 표현되는 지역공동체의 경제개발, 개도국 도시화(urbanization) 와 도시 빈곤층 형성 문제, 다양한 지역 거버넌스(local governance) 형성 등 다면적 구도를 바탕으로 형성되어야 한다는 점을 강조하고 있다.

이러한 문제의식과 새마을 운동 개념 정리, 사업 사례 분석을 바탕으로 향후 새마을 운동 $\mathrm{ODA}$ 확대 가능성 관련 몇 가지 제언을 하고자 한다. 첫째, 새마을운동 ODA는 타 공여기관이 농촌 개발 사업에 적용하는 기본 원리, 농업기술 전수, 사업운영방식, 사업관리기법 등과 차별 성을 가지는 이른바 '한국형 농촌개발사업 콘텐츠’를 쌓아 가야 한다. 이를 위해 KOICA 미얀 마 사업 등 구체적인 사업에 적용된 사업 원리, 한국의 농법 전수, 사업 운영 방식, 특히 지역 사회 지도자 발굴과 주민 자발성을 고취시키는 노하우를 모니터링, 축적해 나가야 한다.

둘째, 사업의 효과성과 성공은 합리적 사업 대상지 선정, 사업의 우선순위 설정으로부터 시 작되며 이는 향후 사업의 확산성에도 큰 영향을 미치는 변수이다12). 사업 대상지 선정에는 빈 곤정도, 빈부격차, 마을의 동질성(직업군, 연령별 인구 분포 등), 규모의 적정성 등이 고려될 수 있다. 예를 들어 미얀마 사업 평가에서도 드러나는 바, 사업 대상지를 좀 더 한정짓고 이 지역을 집중 지원할 필요성이 있다. 또한 사업 수행 전 다각도의 사전 주민 수요조사를 바탕으 로 개발사업의 우선순위를 설정, 우선순위가 높은 사업을 위주로 시행하는 것이 아울러 필요 하다. 향후 사업의 확산을 위해 세 개 마을의 일차 성과평가를 바탕으로 이후 차등 지원하는 방안도 고려해 볼 수 있다.

셋째, 사업의 성공과 확산을 위해서는 적절한 지도자 발굴과 이들에 대한 의식 교육이 무엇 보다 선행되어야 하며, 이는 새마을운동의 성공요인이 새마을 정신에 대한 마을 리더들의 공 감도와 리더에 대한 신뢰를 바탕으로 한 마을 주민의 자발적 동기부여 형성 정도와 매우 밀접 한 관계에 있기에 더욱 그러하다. 교육은 우선 마을 지도자가 지역 연수원이나 지방 공무원을

12) 이울러 사업 대상 지역 사회에 대한 정확하고도 다면적인 사전 정보 수집과 이를 바탕으로 한 사업 관리 방식의 매뉴얼 이 작성되어야 한다. 이는 해당 지역의 사업 성공 가능성을 높여주며, 반대로 리스크는 최소화할 수 있게 한다. 사업 대 상지에 대한 사전 정보 수집 결과 부정적인 평가가 내려지면 그 사업은 과감히 포기하는 것도 중요하다. 왜냐하면 특정 국가, 지역의 경우 문화적, 역사적 요인에 의해 새마을 운동의 정신 전파가 환경적, 구조적으로 제약을 받는 지역이 존재 할 수 있기 때문이다. 
통해 의식 교육을 이수하게 한 후, 이들이 마을에서 주민을 대상으로 관련 교육을 시키게 하는 방식을 택할 수 있다. KOICA는 이 과정을 주관하고 교육 교재 등을 개발, 보급할 수 있다.

넷째, 새마을운동 ODA 사업의 성공과 확산을 위해서는 상시적인 모니터링과 사후관리가 중 요하다. 즉, 새마을운동 $\mathrm{ODA}$ 사업은 보다 장기적 관점에서 지속적으로 시행착오를 수정해 나 가는 사업이 되어야 하며, 사업의 성과를 유지, 발전, 확산시켜 나가기 위해서는 지속적인 관 심을 바탕으로 한 모니터링과 해당 사업의 운영과 관리 기법을 변화된 환경에 맞게 끊임없이 새롭게 하는 노력이 필요하다. KOICA 미얀마 사업의 경우도 향후 전문가의 지속적인 사업 현 장 점검과 자문, 그리고 새로운 기술의 전수 등을 통한 사후관리, 후속 지원 사업을 통해 보다 모범적인 사례로 형성될 수 있을 것이다.

다섯째, 사업의 진전과 함께 초기 하향식(top-down) 방식에서 벗어나, 현장의 요구와 열망 을 보다 반영하는 상향식(bottom-up) 사업을 의도적으로 유도해야 한다. 이는 앞서 언급한 마을 주민의 자발적 동기부여 형성과 연관성을 가지며, 사업 형성 시 이미 그 시기와 단계가 설정되어야 한다. 몽골 사업의 경우 그간 한국의 여러 지자체들의 활발한 하향식 지원 사업 전 개에도 불구하고 아래로 부터의 호응을 불러일으키는 데는 성공하지 못하고 있는 것도 이러한 계획의 부재에서 비롯되었다고도 볼 수 있으며, 이는 향후 사업의 확산성에 구조적 제약으로 작용할 수 있다는 점을 주지해야 할 것이다. 


\section{참고문헌}

\section{〈국내문헌〉}

김성규(2013), 개도국 지역공동체개발 논의 동향과 전망 : 새마을운동 ODA정책과 사업전략 형성을 위한 시사점, 개발협력 정책과 이슈 11호, 2013년 7월, KOICA.

김성규(2013), 개도국 지역공동체개발 사업 사례 연구 : 새마을운동 ODA 확대 가능성을 중심으로, 개발과 이슈 13 호, 2013년 10월, KOICA

김영수, 이광우, 권주형(2008), 지역경제 활성화를 위한 사회적 기업에 관한 탐색적 연구 : 커뮤니티 비즈니스를 중심으로, 지식경영연구, 제 9 권, 1 호.

김영주·박남희(2012), 지속가능한 커뮤니티 관점에서 본 일본의 마을 만들기 사례 분석, 한국가정관리학 회지, 제 30 권 4 호.

김찬호(1998), 일본 마을 만들기의 전개와 의미, 도시와 빈곤, 통권 32호.

김찬호(2000), 일본의 도시화 과정에서 마을 만들기의 전개와 주민참여, 도시행정학보, 제 13 권 제 1 호.

문종화(2012), 마을 만들기 사례분석을 통한 지방자치단체의 역할에 관한 연구- 한국과 일본사례를 중심으로, 한국지역사회발전학회 논문집, 제 37 권 제 1 호.

소진광, 정갑진, 임형백(2011), 새마을운동 ODA 시범사업의 추진방안 연구, 사단법인 환경과 문명, 행정안전부

소진광(2007), 아시아 개발도상국에서의 새마을운동 시범사업 성과평가- 라오스와 캄보디아를 중심으 로, 한국지역개발학회지, 제 19 권 제 4 호, pp179-202

손혁상, 장지순(2008), 새마을운동의 국제개발협력사업화 현황 분석과 대안적 접근모색 : 권리에 기반 한 접근(RBA)과의 접목 가능성을 중심으로, 세계지역연구논총 29집 3호, pp87-110.

안혜원, 이민규(2010), 지역 활성화를 위한 커뮤니티 비즈니스 도입방안, 한국행정학회, 한국행정학회 하계학술발표논문집.

엥흐바야르 오랑거(2009), 한국과 몽골의 협력관계의 재정립 : “새마을 운동” 몽골 적용 사례를 중심으로, 숭실대학교 정치학과 석사학위논문.

유석춘, 장미혜(2003), 사회자본과 한국사회, “사회자본”, 도서출판 그린. 
이종수, 권찬호(2011), ODA 통합에 관한 연구 : 몽골 새마을운동 ODA를 중심으로, 2011 한국정책학회 동계학술대회 자료집, p.153-176.

이종수(2010), 우리나라와 몽골 새마을운동 거버넌스 : ODA와 새마을운동의 거버넌스 접근, 새마을운 동과 지역사회개발연구, 제6권, 경운대 새마을아카데미, p143-168.

임경수(2012), 사회적 자본과 거버넌스 차원에서 본 새마을 운동, 지방행정연구 제 26 권, 통권 90 호, pp. $27-58$

임형백(2011), 새마을 운동을 이용한 아시아 국제개발협력, 아시아연구 14(2), pp.111-139.

정기환(2007), 개도국 농촌개발과 KOICA의 역할, 〈국제개발협력〉 제2호, KOICA, p.33-60.

한도현(2012), 2011 경제발전경험모듈화사업 : 새마을운동 모범사례, 행정안전부, 새마을운동중앙회.

함유근, 김영수, 이국희, 이석준(2008), 지역 사업의 지속 가능성 결정요인 : SLEN 이론에 따른 국내 사례 연구, 중소기업연구, 제 30 권, 제 2 호.

\section{〈기타 자료〉}

경기도 새마을회, 국제협력사업 사업결과보고서 : 몽골, 내부 자료, 2010

국제개발협력위원회(2010), 새마을운동 ODA 사업 평가결과, 제8차 국제개발협력 실무위원회.

$\mathrm{KOICA}$, 미얀마 흘레구 지구 농업, 농촌개발 사업 최종 평가서, 2011

미얀마 흘레구 타운 Micro Finance Office, 내부 자료, 2013

Ministry of Agriculture, Yangon, Self-evaluation of Hlegu Township Agricultural and Rural Development Program, 2011

\section{〈국외 문헌〉}

Bezemer, Dirk and Derek Headey(2008). "Agriculture, Development, and Urban Bias."World Development, V ol.36, No.8,pp.1342-1364.

Douglass, M. (1994), “The 'Developmental State' and the Asian Newly Industrialized Economies," Environment and Planning A,26, pp. 543-566.

Douglass, M. (2000), Turning Points in the Korean Space-Economy-from the Developmental State to Intercity Competition, 1953-2000, Asia/Pacific Research Center, Institute for International Studies, Stanford University, Monograph. 
Douglass, M. (2009), "Globopolis or Cosmopolis? -- Alternative Futures of City Life in East Asia,” Studiesin Urban Humanities, 2, pp.67-115.

Douglass, M., The Saemaul Undong in Historical Perspective and in the Contemporary World, Unpublished paper, to be published in 2013 by UNRISD \& KOICA.

Goh, Kun(2010), Saemaul(New Village) Movement in Korea - Factors of the Success and Their Transferability, SMU 40th Anniversary International Symposium

McNicoll, G.(2006), "Policy Lessons of the East Asian Demographic Transition," Population and Development Review, 32:1, pp.1-25.

World Bank(2005), East Asia Decentralizes- Making Local Government Work. World Bank, Wash., D. C.

Wheeler, D., McKague, K., and Thomson, J.(2003), Sustainable Livelihoods and the Private Sector: How Development Agencies Can Strengthen Sustainable Local Enterprise Network, Final Report, School of Business, York University.

Reed, Edward P.(2010), Is Saemaul Undong a Model for Developing Countries Today?, Paper prepared for International Symposium in Commemoration of the 40th Anniversary of Saemaul Undong Hosted by the Korea Saemaul Undong Center. 